\title{
Weather During Critical Epidemiological Periods and Subsequent Severity of Powdery Mildew on Grape Berries
}

Michelle M. Moyer, Department of Horticulture, Washington State University, Irrigated Agriculture Research and Extension Center, Prosser, WA 99350; and David M. Gadoury, Wayne F. Wilcox, and Robert C. Seem, Division of Plant Pathology and Plant-Microbe Biology, Cornell University, New York State Agricultural Experiment Station, Geneva, NY 14456

\begin{abstract}
Moyer, M. M., Gadoury, D. M., Wilcox, W. F., and Seem, R. C. 2016. Weather during critical epidemiological periods and subsequent severity of powdery mildew on grape berries. Plant Dis. 100:116-124.

Recorded severity of grape powdery mildew on berries of untreated, susceptible hybrid cultivars varied from 0.2 to $50.5 \%$ across a 30 -year period in Geneva, NY; within 7 of those years, cluster disease severity ranged from 3.42 to $99.5 \%$ on Vitis vinifera 'Chardonnay'. Although existing temperature-driven risk models could not account for this annual variation, pan evaporation $\left(\mathrm{E}_{\mathrm{pan}}\right)$, an environmental variable influenced by the collective effects of temperature, vapor pressure deficit, solar radiation, and wind speed, did. Logistic regression analysis (LRA) was used to classify epidemics as either mild or severe. Recursive partition analysis (RPA) provided

a simplified decision tree for calculation of powdery mildew risk and incorporated (i) an estimate of the relative primary inoculum levels based on temperatures in the previous late summer and (ii) the current season favorability for pathogen development during the grapevine phenological period critical for berry infection by Erysiphe necator. Although the LRA had fewer instances of misclassification, RPA provided a rapid means for seasonal risk classification. Both the RPA and LRA models are able to describe disease severity risk in real time or can be used to forecast risk, thereby allowing growers to adjust management programs in a responsive manner.
\end{abstract}

Vitis vinifera, domesticated in Europe and grown globally, represents the standard genetic base for wine, table, and raisin grape production. The relationship between this European-native host species and the powdery mildew parasite (Erysiphe necator, syn. Uncinula necator) of Vitis spp. originating from North America, is relatively new, with formal descriptions of epidemics in Europe published in 1845 (Large 1940). Nearly all cultivars of $V$. vinifera, as well as many interspecific hybrid cultivars with $V$. vinifera parentage, are highly susceptible to powdery mildew. Hence, the commercial production of mildew-susceptible grape requires applications of fungicides to prevent or suppress disease development.

The vegetative and floral development of grapevine results in three parallel but distinct epidemics of powdery mildew: one on foliage, one on berries, and one on the rachis. Grapevines have indeterminate vegetative growth; consequently, the canopy is functionally treated as a population of host tissues that do not acquire complete ontogenic resistance during the growing season, and there is a relatively long period during which the canopy must be protected from infection (Nail and Howell 2005; Pearson and Gadoury 1992; Pool et al. 1984). In contrast, inflorescence emergence and flowering of grapevines occurs during a relatively short period, and developing berries rapidly acquire ontogenic resistance to powdery mildew (Gadoury et al. 2003a). This results in a narrow temporal window for berry infection (Ficke et al. 2002, 2003, 2004; Gadoury et al. 2003b). The rachis never completely develops ontogenic resistance (Gadoury et al. 2001). Nonetheless, in commercial vineyards, rachis and berry infection are managed similarly. In cool climates, exemplified by New York State or Rheinhessen, Germany, severity of powdery mildew on $V$. vinifera berries can vary substantially from year to year (Gadoury et al. 2001, 2007; Hill 1990; Moyer et al. 2007). Production of highquality fruit requires effective prevention of pathogen colonization during the critical phenological period of susceptibility of berries, in conjunction with viticultural practices that enhance fruit exposure

Corresponding author: M. M. Moyer; E-mail: michelle.moyer@wsu.edu

Accepted for publication 16 June 2015 .

http://dx.doi.org/10.1094/PDIS-12-14-1278-RE

(C) 2016 The American Phytopathological Society to light and fungicide spray penetration of the fruiting zone (Austin and Wilcox 2011; Smart and Robinson 1991; Zahavi et al. 2001). However, most research and current models used to deduce disease risk (Calonnec et al. 2008; Carisse et al. 2009; Chellemi and Marois 1991a; Gubler et al. 2009; Kast 1997; Kast and Bleyer 2010) do not provide clear separation between the likely development of powdery mildew on grapevine foliage versus fruit, and it is unclear whether effective disease management might be limited by this approach.

Multiple disease development models exist, used to deduce risk and aid in decision making for grape powdery mildew management. Of the models currently in use by regional growers, the model by Caffi et al. (2012) has been successful in predlicting primary infection events, thus allowing growers to more precisely time earlyseason management programs. The OiDiag 2.2 model (Kast and Bleyer 2010) focuses on predicting primary inoculum load and subsequent disease development to help determine both the timing of the initial management choice and spray interval selection. One of the more widely applied and evaluated models, the University of California-Davis Powdery Mildew Risk Index (Gubler et al. 2009), includes a season-long approach but with a specific focus on midseason mildew development to improve spray interval selection and reduce unnecessary mid- and late-season sprays. Various other regional models require inputs from repeated scouting and are initiated or based on visual detection of symptoms (Savary et al. 2009), or use the detection of conidia above a specified air concentration (Carisse et al. 2009) to initiate management intervention. Some models include rainfall as a factor limiting epidemic development (Chellemi and Marois 1991a; Sall 1980), or use rain events to serve as an indicator of primary inoculum availability (ascospore release) (Caffi et al. 2011). The models using temperature as an input tend to focus on the cardinal and lethal temperatures reported for E. necator (Calonnec et al. 2008; Chellemi and Marois 1991b; Delp 1954; Gubler et al. 2009; Peduto et al. 2013; Sall 1980). In cooler climates, where midsummer temperatures seldom reach levels that are lethal to E. necator (Carisse et al. 2009; Hill 1990), models that invoke rules to suppress predicted disease increase during periods of high temperatures (Calonnec et al. 2008; Gubler et al. 2009) may overpredict disease severity when temperatures fail to reach a deleterious level and, instead, remain within the optimal range for pathogen growth. For example, in New York, the first powdery mildew colonies are typically detected in vineyard surveys approximately 1 month after budbreak 
(i.e., approximately 30 May) (Gadoury et al. 1997a, 2001). During the months of June, July, and August, daily temperatures generally remain within the optimal temperature range for powdery mildew of 20 to $30^{\circ} \mathrm{C}$ (Delp 1954; Moyer et al. 2007), and aerial temperatures high enough to be suppressive or lethal to pathogen spread and survival are rare, although some grape tissues exposed to direct sunlight might reach temperatures within the deleterious range (Austin and Wilcox 2012).

Within plantings of grapevine cultivars susceptible to powdery mildew in New York, the occurrence of years with uncharacteristically high or low levels of the disease on fruit suggests that macroscale weather patterns may be involved in annual variations in disease severity on grape berries. The synchronous bloom of grapevines in this climate, how that relates to the uniform onset of ontogenic resistance within a vineyard (Gadoury et al. 2003a), and the resulting narrow chronological period of berry susceptibility (Ficke et al. 2003, 2004; Gadoury et al. 2003b; Gee et al. 2008) collectively delineate a period during which the effect of such weather patterns could be exerted. Therefore, a focus on weather during the ontogenically relevant period of berry development could provide a means to forecast favorability for berry infection during individual years across a broad geographic region. In particular, this approach might provide some advance warning of years sharing key macroscale features that typify when severe berry infection might be expected, or years sharing macroscale features associated with levels of berry infection significantly below average. Both scenarios would allow producers to better reconcile the intensity of a management program to the risk of berry infection.

The objectives of this study were to (i) define the macroscale environmental conditions that are historically correlated with both regionally mild and severe powdery mildew infection on grape berries in New York State, (ii) develop an empirical model describing this relationship, and (iii) derive decision rules from the model suitable for testing by commercial wine grape growers who may need support for disease management decisions.

\section{Materials and Methods}

Historical data. Model development was based on records of the severity of fruit infection at harvest, expressed as the percentage of the total cluster surface that was visibly colonized by E. necator. The sites from which the data were collected for model development and validation consisted of a 0.5 -ha planting of the Vitis interspecific hybrid 'Rosette' and a 0.5 -ha interplanting of Vitis hybrid 'Delaware' at the New York State Agricultural Experiment Station (NYSAES) at Geneva, NY. An additional Rosette site was used in 1981, located at Naples, NY. Rosette is rated as highly susceptible to powdery mildew, although its berries are less susceptible than those of most $V$. vinifera cultivars; Delaware is rated as moderately susceptible (Wilcox et al. 2010). Disease was assessed on unsprayed vines for the years 1981 and 1983 to 2011 (Gadoury et al. 1997b; Pearson and Riegel 1984, 1985, 1986, 1987, 1988, 1990, 1991, 1992, 1993, 1994, 1995, Pool et al. 1984; Wilcox and Riegel 1996, 1997, 1998, 1999, 2000, 2001, 2002, 2003, 2004a, 2005, 2006a, 2007b, 2008b, 2010c,d, 2012a,b). No disease evaluations were conducted in 1982; thus, data from that year was not included in this study. To compare how the developed model also performed on $V$. vinifera cultivars, historical disease data from unsprayed $V$. vinifera 'Chardonnay' vines at research sites at NYSAES and near Dresden, NY (approximately $20 \mathrm{~km}$ southeast of NYSAES) were also used, encompassing the years 2003 and 2005 to 2010 (Wilcox and Riegel 2004b, 2006b, 2007a, 2008a, 2010a,b, 2012c). Summaries of relevant disease severity data, source, and grapevine phenology are presented in Table 1 (model development) and Table 2 (model validation). Disease severity data used for model development were collected from the Rosette vineyard to reduce potential confounding of the effects of the year-to-year variation in macroscale climatic factors. The data used for subsequent model validation was sourced from the vineyards of either Delaware or Chardonnay, in addition to the Rosette vineyard for the years not used in model development. The years selected for model validation in the Rosette vineyard were representative of years with high and low disease severity.
Daily weather records for the above years were obtained from the National Oceanic and Atmospheric Administration (NOAA) for the NOAA Benchmark Weather Station number 3031840 at NYSAES. The weather station is located approximately $900 \mathrm{~m}$ northeast of the Rosette vineyard, at $42^{\circ} 52.6^{\prime} \mathrm{N}, 77^{\circ} 01.9^{\prime} \mathrm{W}$; is $218 \mathrm{~m}$ above sea level; and includes a Class A Meteorological Evaporation Pan. For each year of disease data, weather data from the preceding year and current year were used due to the multiyear nature of powdery mildew epidemics. Weather variables recorded and analyzed included minimum, maximum, and average daily temperature $\left(\mathrm{T} ;{ }^{\circ} \mathrm{C}\right)$; daily net solar radiation $\left(\mathrm{SR} ; \mathrm{W} \mathrm{m}^{-2}\right)$; average daily vapor pressure deficit

Table 1. Erysiphe necator cluster severity ratings and related grapevine phenology for the Vitis interspecific hybrid 'Rosette' in Geneva, NY used for New York model development

\begin{tabular}{|c|c|c|c|c|}
\hline Year & $\begin{array}{l}\text { Cluster disease } \\
\text { severity }(\%)^{\mathrm{a}}\end{array}$ & $\begin{array}{c}\text { Budbreak } \\
(\text { (BBCH 07) }\end{array}$ & $\begin{array}{c}\text { Bloom } \\
(\text { BBCH 61) }\end{array}$ & $\begin{array}{c}\text { Days between } \\
\text { budbreak and bloom }\end{array}$ \\
\hline 1986 & 48.2 & 28 April & 11 June & 44 \\
\hline 1987 & 8.2 & 4 May & 10 June & 37 \\
\hline 1988 & 0.2 & 10 May & 10 June & 31 \\
\hline 1989 & 47.7 & 9 May & 19 June & 41 \\
\hline 1990 & 6.4 & 28 April & 16 June & 49 \\
\hline 1991 & 2.9 & 1 May & 5 June & 35 \\
\hline 1992 & 50.1 & 11 May & 26 June & 46 \\
\hline 1993 & 3.4 & 1 May & 21 June & 51 \\
\hline 1994 & 36.8 & 1 May & 17 June & 47 \\
\hline 1995 & 7.3 & 1 May & 21 June & 51 \\
\hline 1996 & 31.0 & 1 May & 23 June & 53 \\
\hline 1997 & 25.8 & 1 May & 25 June & 55 \\
\hline 1998 & 9.4 & 1 May & 10 June & 40 \\
\hline 1999 & 4.0 & 1 May & 15 June & 45 \\
\hline 2000 & 6.2 & 1 May & 24 June & 54 \\
\hline 2001 & 2.5 & 1 May & 23 June & 53 \\
\hline 2002 & 4.0 & 1 May & 25 June & 55 \\
\hline 2003 & 46.7 & 1 May & 28 June & 58 \\
\hline 2004 & 9.0 & 1 May & 21 June & 51 \\
\hline 2005 & 11.4 & 1 May & 16 June & 46 \\
\hline 2006 & 24.6 & 7 May & 16 June & 40 \\
\hline 2007 & 8.9 & 10 May & 13 June & 34 \\
\hline
\end{tabular}

a Cluster severity as percent surface area of cluster diseased.

b If phenological data were not available, assumption was set as budbreak $=1$ May and bloom $=21$ June, denoted by a "+". Budbreak is defined as when $50 \%$ of the buds were at $\mathrm{BBCH} 07$; bloom is defined as when $50 \%$ of the inflorescences are at BBCH 61.

Table 2. Powdery mildew cluster severity ratings and related grapevine phenology in New York used for model validation

\begin{tabular}{|c|c|c|c|c|}
\hline Year & $\begin{array}{c}\text { Cluster disease } \\
\text { severity }(\%)\end{array}$ & $\begin{array}{c}\text { Budbreak } \\
\left(^{(B B C H ~ 07)^{a}}\right.\end{array}$ & $\begin{array}{c}\text { Bloom } \\
(\text { BBCH 61 })^{\mathrm{a}} \\
\end{array}$ & Cultivar \\
\hline 1981 & 42.0 & $1 \mathrm{May}^{+}$ & 21 June $^{+}$ & Rosette \\
\hline 1983 & 1.6 & $1 \mathrm{May}^{+}$ & 21 June $^{+}$ & Delaware \\
\hline 1984 & 32.3 & $1 \mathrm{May}^{+}$ & 21 June $^{+}$ & Rosette \\
\hline 1985 & 14.0 & 3 May & 21 June & Rosette \\
\hline 2003 & 98.4 & 1 May $^{+}$ & 21 June & Chardonnay \\
\hline 2005 & 3.42 & $1 \mathrm{May}^{+}$ & 24 June & Chardonnay \\
\hline 2006 & 67.4 & $1 \mathrm{May}^{+}$ & 28 June & Chardonnay \\
\hline 2007 & 17.9 & $1 \mathrm{May}^{+}$ & 19 June & Chardonnay \\
\hline 2008 & 25.8 & $1 \mathrm{May}^{+}$ & 21 June & Chardonnay \\
\hline 2008 & 2.8 & 28 April & 13 June & Rosette \\
\hline 2009 & 99.9 & $1 \mathrm{May}^{+}$ & 23 June & Chardonnay \\
\hline 2009 & 23.0 & 29 April & 19 June & Rosette \\
\hline 2010 & 99.5 & $1 \mathrm{May}^{+}$ & 14 June & Chardonnay \\
\hline 2010 & 50.5 & $1 \mathrm{May}^{+}$ & 16 June & Rosette \\
\hline 2011 & 29.3 & 14 May & 21 June & Rosette \\
\hline
\end{tabular}

${ }^{a}$ If phenological data were not available, assumption was set as budbreak $=1$ May and bloom $=21$ June, denoted by a "+" symbol. Budbreak is defined as when $50 \%$ of the buds were at $\mathrm{BBCH} 07$; bloom is defined as when $50 \%$ of the inflorescences are at $\mathrm{BBCH} 61$. 
(VPD; $\mathrm{kPa}$ ); minimum, maximum, and average daily relative humidity $(\mathrm{RH})$; total daily pan evaporation $\left(\mathrm{E}_{\mathrm{pan}} ; \mathrm{mm}\right)$; and total daily precipitation $(\mathrm{mm})$. Available hourly data sets included temperature, RH, surface wetness, and precipitation. Weather data were collected at 15-min intervals and processed (averaged) to produce hourly averages. The hourly averages were used to determine daily maximum and minimum values. Daily maximum and minimum values were used to determine daily averages.

Development of a New York model. Our goal was to use the historical data to develop a model to assess the risk of mild or severe levels of fruit infection developing by harvest, as defined by percent surface area of the cluster colonized by the fungus, based upon key environmental and biological conditions occurring beforehand. In initial analysis for model development (Table 1), disease severity in each year was classified as either Severe (>20\%), Intermediate $(>6 \%$ and $<20 \%)$, or Mild $(<6 \%)$ disease severity. These classifications were chosen based on the distribution of disease severity among the years analyzed. After initial categorization and consultation with potential end-users, only two categories of disease ratings were desired because growers would practically manage Intermediate years as if they were Severe. With this in mind, using information on what would be considered "acceptable" levels of disease severity by the local industry and reviewing the distribution of disease ratings in the model validation data set, the classification of Severe or Mild was redefined as $\geq 9 \%$ and $<9 \%$, respectively.

Combinations of linear and logistic regression analyses were used to determine the environmental parameters that yielded the highest correlation coefficients and lowest root mean squared error, for the greatest predictive value of powdery mildew severity on clusters (expressed as a continuous variable [log transformed]) for each of the 30 seasons of available data. Several weather inputs were evaluated; those selected and their rationales are presented in Table 3.

In addition to logistic regression being used to determine disease severity on clusters, it was performed using the categorized disease ratings of Severe and Mild, as previously described. Analysis of variance of the regression models identified whether the models were a significantly better description of the interaction between year and disease severity than the disease severity means alone. For logistic regression analysis (LRA), where the output was probability of a Severe categorization, the practical categorization of a Severe year was adjusted using receiver operating characteristic (ROC) curve analysis to compare sensitivity and specificity of the developed model (Hilbe 2009). For the logistic regression model, a year was categorized as Severe if the predicted probability from the model was at or greater than the cut-point based on analysis of the ROC curve (Fig. 1). The selected cut-point for the probability of Severe was

Table 3. Rationale and variables used for development of the New York powdery mildew risk index

\begin{tabular}{|c|c|}
\hline Rationale & Variables used $^{\mathbf{a}}$ \\
\hline $\begin{array}{l}\text { Related to the development of } \\
\text { ascocarps during the previous fall }\end{array}$ & $\begin{array}{l}\mathrm{DD}_{10} \text { from the previous late summer, } \\
\text { starting } 1 \text { August, to early autumn, } \\
\text { ending on } 31 \text { October, with various } \\
\text { combinations within that time frame }\end{array}$ \\
\hline $\begin{array}{l}\text { Related to the subsequent survival } \\
\text { of ascocarps into the current } \\
\text { growing season }\end{array}$ & $\begin{array}{l}\mathrm{DD}_{10} \text { of the current year from } \\
1 \text { January to } 1 \text { May, with various } \\
\text { combinations within that time frame }\end{array}$ \\
\hline $\begin{array}{l}\text { Related to weather parameters } \\
\text { previously indicated as being } \\
\text { related to powdery mildew disease } \\
\text { development, and inclusive of the } \\
\text { period of peak berry susceptibility } \\
\text { for Erysiphe necator during the } \\
\text { current growing season }\end{array}$ & $\begin{array}{l}\text { Average daily RH, SR, VPD, and T } \\
\text { from } 1 \text { May to } 31 \text { July; daily } \mathrm{E}_{\mathrm{pan}} \\
\text { from } 1 \text { May to } 31 \text { July averaged } \\
\text { over various time spans (e.g., } \\
\text { weekly); and cumulative } \\
\text { precipitation between } 1 \text { May and } \\
31 \text { July of the current year }\end{array}$ \\
\hline
\end{tabular}

${ }^{\text {a }} \mathrm{DD}_{10}=$ degree-day accumulation using $10^{\circ} \mathrm{C}$ base temperature, and calculated from the daily maximum and minimum temperatures, as described in the text; $\mathrm{RH}=$ relative humidity; $\mathrm{SR}=$ solar radiation; $\mathrm{VPD}=$ vapor pressure deficit; $\mathrm{T}$ = temperature; $\mathrm{E}_{\mathrm{pan}}=$ evapotranspiration measured from a Class $\mathrm{A}$ meteorological pan. a predicted probability of $\geq 0.29$; this was chosen because it was the point that maximized true positives (prediction of Severe when the final disease ratings indicated Severe) and minimized false negatives (prediction of Mild when, in fact, disease ratings indicated Severe). The choice to use a cut-point that would eliminate false negatives was made because the consequences (crop loss) are greater if practical management strategies were developed for a Mild year when, in fact, it was a Severe year.

Recursive partition analysis (RPA), with categorized Mild or Severe cluster disease ratings, was used to develop a decision tree for epidemic classification (Cook and Goldman 1984). The application of an RPA is to develop a hierarchy of "questions" to help make quick predictions (or, in the case of the medical field, diagnoses) regarding a given situation. RPA calculated the probability of categorizing a given year as Severe or Mild, based on a combination of threshold values of average daily $\mathrm{E}_{\mathrm{pan}}$ and cumulative $\mathrm{DD}_{10}=$ degree-day accumulation using $10^{\circ} \mathrm{C}$ base temperature $\left(\mathrm{DD}_{10}\right)$ from the late summer of the previous year for time frames that were identified in the initial data screen. After each set of questions, the population of site-variety combinations was either categorized into a final prediction or subjected to the next classification question. This was continued until all individual site-variety combinations were categorized. The splitting process (the different questions) is done to maximize the likelihood-ratio $\chi^{2}\left(\mathrm{G}^{2}\right)$, and to maximize the rate (the number of observations falling into a single response category; e.g., $100 \%$ of the responses are categorized as Severe and none as Mild after a specific question is answered). The output categories were defined by the percentage of the year-variety combinations within a category in which final disease classification were actually Severe or Mild. There were four final prediction categories for this RPA, defined as the percentage of years falling into that disease severity category: $100 \% \mathrm{Se}-$ vere, $100 \%$ Mild, $60 \%$ Severe, and $80 \%$ Mild.

Validation of the New York model. Site, variety, and year data used for model validation are presented in Table 2. For model validation using disease ratings for Chardonnay, a different threshold of disease severity was defined for classifying a year as Severe or Mild, due to the higher level of disease severity typically seen on Chardonnay relative to Rosette or Delaware. For Chardonnay, a year was considered Mild if disease severity on clusters was $<58 \%$ and Severe when cluster disease severity was $>58 \%$. This threshold was selected by comparing typical disease rating distributions in a given year on Chardonnay compared with the similar disease distributions seen on Rosette.

For both the RPA and LRA models, additional analyses were performed, where the daily average $\mathrm{E}_{\mathrm{pan}}$ was also calculated in

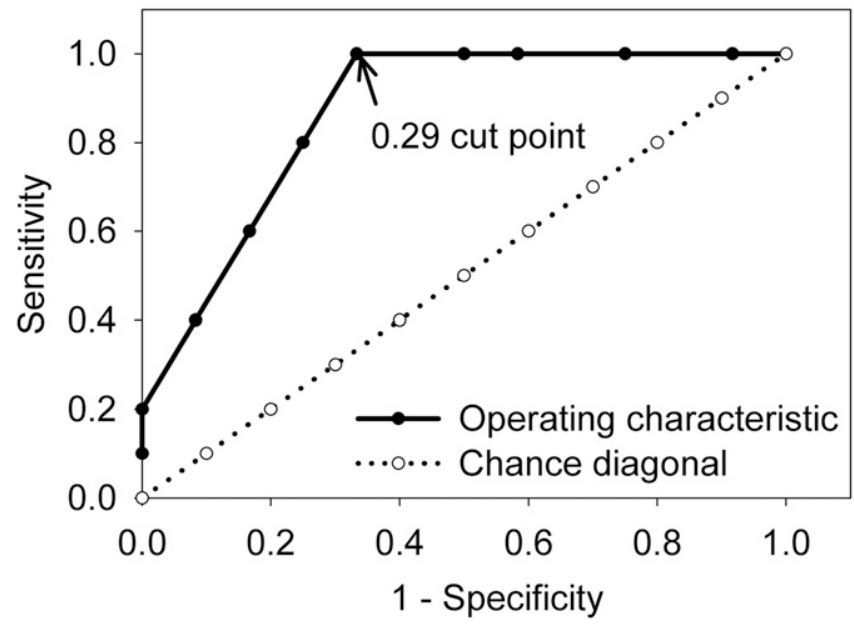

Fig. 1. Receiver operator characteristic curve for the validation data set used in the logistic regression analysis model development. The cut-point selected for the probability of Severe was a predicted probability of $\geq 0.29$. This cut-point was selected to maximize sensitivity rather than specificity, due to the production consequences of managing a year as if it were Mild when in fact, it is Severe (i.e., a false negative). 
consecutive cumulative weeks from 1 June and 2 August, rather than only considering the overall average daily $\mathrm{E}_{\mathrm{pan}}$ value for the entire 6 -week time frame. For example, the daily average $\mathrm{E}_{\mathrm{pan}}$ for the week of 1 to 7 June, which was calculated on 7 June, was an average of daily $E_{p a n}$ values for the previous 7 days. The average daily $E_{p a n}$ calculated on 14 June was an average of daily $\mathrm{E}_{\text {pan }}$ values for the previous 14 days, and so on. The continuous averaging was a means to describe long-term trends in environmental favorability for powdery mildew development during different stages of the critical period for berry susceptibility during the growing season.

Comparison of observed and calculated evaporation and the use of calculated evaporation for disease risk forecasting. Because a Class A Meteorological Evaporation Pan is no longer a commonly used instrument, evapotranspiration $\left(\mathrm{E}_{\mathrm{to}}\right)$ was substituted as a surrogate, and was calculated by the FAO Penman-Monteith equation (Allen et al. 1998), with modifications. Modifications to the $\mathrm{E}_{\mathrm{to}}$ calculations were as follows: average temperature was calculated as the average of the maximum and minimum daily temperature $\left(\mathrm{T}_{\max }\right.$ and $\mathrm{T}_{\min }$, respectively); soil heat flux density (G) was set to 0 ; saturation vapor pressure $\left(\mathrm{e}_{\mathrm{s}}\right)$ was considered the average of the vapor pressure deficits at $\mathrm{T}_{\max }$ and $\mathrm{T}_{\min }$; actual vapor pressure $\left(\mathrm{e}_{\mathrm{a}}\right)$ was replaced with an average calculated vapor pressure using the combination of $\mathrm{T}_{\max }$ at $\mathrm{RH}_{\min }$ (maximum VPD) and $\mathrm{T}_{\min }$ at $\mathrm{RH}_{\max }$ (minimum VPD); and slope of the vapor pressure curve $(\Delta)$ was calculated as the average between slopes at $T_{\max }$ and $T_{\min }$. Calculated $E_{\text {to }}$ was regressed against observed daily $\mathrm{E}_{\mathrm{pan}}$ from 1 May to 30 September for the years 1985 to 2007 . For days when key input records were missing, $\mathrm{E}_{\text {to }}$ was not calculated.

A comparison was also made between observed $\mathrm{E}_{\mathrm{pan}}$ and calculated $\mathrm{E}_{\text {to }}$ using a version of the Penman-Monteith equation that calculated evaporation from an open water surface $\left(\mathrm{E}_{\mathrm{ow}}\right)$ (Feddes and Lenselink 1994). Evaporation from an open water surface is similar to that from a Class A Meteorological Evaporation Pan; modifications to the equation were the same as listed above. The rationale behind this comparison was that transpiration resistance for a fungal pathogen wholly external to the host plant would be adequately simulated by evaporation from an open body of water.

The resulting calculated $\mathrm{E}_{\text {to }}$ and $\mathrm{E}_{\mathrm{ow}}$ values were then processed through the models derived from LRA and RPA. Calculated $\mathrm{E}_{\text {to }}$ and $\mathrm{E}_{\mathrm{ow}}$ for the years used to develop those models were used to evaluate whether these calculated evaporation values would be appropriate substitutes in situations where measured $\mathrm{E}_{\text {pan }}$ values are not available. In the comparison, data from 2002 and 2004 were not used due to missing wind data and, thus, evaporation could not be calculated. Regression between observed evaporation $\left(\mathrm{E}_{\mathrm{pan}}\right)$ and calculated evaporation $\left(\mathrm{E}_{\mathrm{to}}\right.$ and $\mathrm{E}_{\mathrm{ow}}$ ) for the period of 1 June to 31 July was conducted to compare values, and to determine whether adjustments to the calculated values would be necessary to optimize them for model use. The number of false positives and false negatives resulting from using $\mathrm{E}_{\mathrm{pan}}, \mathrm{E}_{\mathrm{to}}$, and $\mathrm{E}_{\mathrm{ow}}$ were compared using both the original calculated values and the adjusted calculated values.

Monte Carlo simulation of calculated $\mathbf{E}_{\text {to }}$ using historical weather inputs. To see the likelihood of high-risk weather patterns aligning with the typical calendar dates that approximate key vine phenological stages, Monte Carlo simulations using historical weather data were used to calculate potential $\mathrm{E}_{\mathrm{to}}$ as described above. Monte Carlo simulation is a method that uses a random sampling of input values within a specified range to determine the frequency of potential numerical outcomes of an algorithm. In the case of calculating $\mathrm{E}_{\mathrm{to}}$, which has a series on input numbers to calculate a final value, this simulation method can provide an estimate of potential $E_{\text {to }}$ values that might occur on a given day and their probability distribution, using the historical ranges of input values seen on that day. For this, historical (1985 to 2007) weekly average $T_{\max }$ and $T_{\min }$, minimum and maximum VPD, wind speed, and SR were used for each corresponding calendar week in each year. As a part of the sampling strategy for input variables in the Monte Carlo simulation, the sampling range of the historical data were limited to those values falling into an $80 \%$ tolerance interval for the population and a $95 \%$ confidence interval for the values (i.e., a 95\% confidence interval that would include
$80 \%$ of the population values). These modified input ranges were then used in the calculations of $\mathrm{E}_{\mathrm{to}}$, while soil heat flux and psychometric constant were held constant, and the slope of the vapor pressure curve changed with changing temperature inputs. The simulation was run using a Microsoft Excel-based spreadsheet, and calculations were based on 5,000 combinations per calendar week. In each combination, a random number from within the range of inputs that were variable was selected and used in the deterministic calculation of $\mathrm{E}_{\mathrm{to}}$. An aggregation of the output from the 5,000 combinations per for each calendar week were used to determine the distribution of possible $E_{t o}$ values based on the input ranges for that week.

Statistical analyses. All statistics were performed using JPM Statistical Software (SAS Institute, Inc., Cary, NC). Details relating to the specific modeling actions are described in the aforementioned sections.

\section{Results}

Development of a New York model. Initial data screening used only those years in the model development data set (Table 1) that had a disease severity rating of $<6 \%$ and $>20 \%$, to identify key variables driving the two distinctive disease outcomes. LRA of log-transformed cluster severity ratings against various weather parameters showed that both $\mathrm{DD}_{10}$ from 1 August to 15 September the previous growing season, and current year $\mathrm{E}_{\mathrm{pan}}$ from 1 June to 31 July, were significantly correlated with cluster disease severity. DD accumulation was positively correlated to cluster severity ratings (slope significant at $P=0.02$ ), accounting for $35 \%$ of the variance in the dependent variable. Pan evaporation was negatively correlated (slope significant at $P=0.003$ ), and accounted for $68 \%$ of the variance in Severe and Mild disease ratings. When combined for multiple regression, the resulting model accounted for $81 \%$ of the variance. The model effect $\left(\mathrm{E}_{\mathrm{pan}}\right.$ and $\mathrm{DD}_{10}$ ) was significant at $P<0.001$.

After this initial screen, all years for the model development data set (Table 1) were used to determine whether those aforementioned time frames and associated weather parameters were still valid. LRA of log-transformed cluster severity ratings for all years in this model-development data set resulted in a model that accounted for $60 \%$ of the variance, and the model effect $\left(\mathrm{E}_{\mathrm{pan}}\right.$ and $\left.\mathrm{DD}_{10}\right)$ was significant at $P=0.0002$. The regression equation relating cluster disease severity to $\mathrm{E}_{\mathrm{pan}}$ and late summer $\mathrm{DD}_{10}$ was

$$
\log _{(\text {Cluster Severity })}=4.44-1.09\left(\mathrm{E}_{\mathrm{pan}}\right)+0.01\left(\mathrm{DD}_{10}\right)
$$

Although the intercept was only weakly significant $(P=0.10)$, the parameter estimates for $\mathrm{E}_{\mathrm{pan}}$ and $\mathrm{DD}_{10}$ were significantly different from zero $(P=0.0007$ and 0.03 , respectively). From this initial screening, $E_{\text {pan }}$ from 1 June through 31 July and $D_{10}$ from 1 August to 15 September were used in subsequent model development.

The same model development data set (Table 1) was then evaluated using the same environmental variables as predictors but with the dependent variable (disease severity) categorized as either Mild $(<9 \%)$ or Severe $(\geq 9 \%)$. This resulted in a model with a pseudo- $R^{2}$ of 0.31 and a whole-model $\chi^{2}$ test value of 0.009 . The lack of fit $\chi^{2}$ $(P=0.35)$ was not significant, indicating that the model provided an adequate fit to the data. The response equation for the probability of either a Mild or Severe year was:

$$
\begin{aligned}
\operatorname{Prob}(\text { Mild }) & =1 /\left[1+\mathrm{e}^{\left(-0.45+\left(-0.02 * \mathrm{DD}_{10}\right)+\left(1.98 * \mathrm{E}_{\mathrm{pan}}\right)\right)}\right] \\
\operatorname{Prob}(\text { Severe }) & =1-\operatorname{Prob}(\text { Mild })
\end{aligned}
$$

ROC curve analysis had an area under the curve (AUC) of 0.86 . When the cut-point was set to the probability of a Severe prediction of 0.29 , the sensitivity of the model was 1.0 , with a specificity of 0.66 . With this probability threshold for determining a final prediction for Severe, four false positives (prediction of a Severe year when in fact it was Mild) and zero false negatives (prediction of a Mild year when in fact it was Severe) were observed in the 22 years used in building the model. False positives occurred in 1990, 2000, 2002, and 2004, when predicted probability of a Severe year was 0.46 , $0.81,0.51$, and 0.77 , respectively. 
RPA resulted in a three-step decision scheme (tree with advancement to each step and subsequent direction dependent on the value of either $\mathrm{E}_{\mathrm{pan}}$ or $\left.\mathrm{DD}_{10}\right)$. The RPA model had an $R^{2}=0.61$. ROC curve analysis yielded an AUC of 0.89, indicating a high classification accuracy of the decision tree. The first decision point was by $\mathrm{E}_{\mathrm{pan}}$, and divided very dry years $\left(\mathrm{E}_{\mathrm{pan}} \geq 6.07 \mathrm{~mm}\right.$ during the aforementioned time frame) from average to wet years $\left(\mathrm{E}_{\mathrm{pan}}<6.07 \mathrm{~mm}\right)$; in this decision point, $100 \%$ of the site-year combinations that fell into the dry year category were Mild. If the year was average to wet, the second decision point was based on DD accumulation in the preceding year. If the previous summer conditions were warm $\left(\mathrm{DD}_{10} \geq 450\right)$, $100 \%$ of the site-year combinations in this category were Severe. If the previous year was cool $\left(\mathrm{DD}_{10}<450\right)$, the third decision point was based again on $\mathrm{E}_{\mathrm{pan}}$, which divided the remaining years into wet $\left(\mathrm{E}_{\mathrm{pan}}<5.45 \mathrm{~mm}\right)$ or average $\left(\mathrm{E}_{\mathrm{pan}} \geq 6.07 \mathrm{~mm}\right)$. In this final split, $60 \%$ of the site-years falling into the wet category were Severe and $80 \%$ of the site-year combinations falling into the average category were Mild. The sensitivity of this model was 0.95 , while the specificity was 0.00 , indicating the lack of the RPA model to identify true Mild years. Specifically, this decision scheme resulted in 19 true positives (falling into the $100 \%$ Severe or $60 \%$ Severe prediction categories, and the actual disease severity was categorized as Severe); two false positives (2004 and 2006, both of which were fell into the $60 \%$ Severe prediction category but, in fact, were categorized as Mild); and one false negative, where the prediction fell into the $80 \%$ Mild year when it was, in fact, a classified as a Severe year (2005).

Validation of the New York model. The LRA and RPA models developed above were validated using independent data sets (Table 2). Validation of the LRA model for Vitis hybrids (Delaware and Rosette) had a sensitivity of 0.83 and a specificity of 0.50 and resulted in two instances of misclassification: one a false positive and one a false negative (Table 4). In 2008, the probability of a Severe year was 0.73 , which would result in the classification of Severe; however, in fact, the year was Mild (2.8\% disease severity). In 2011, the probability of a Severe year was 0.17 , resulting in a classification of Mild; however, in fact, the year was Severe (29.3\% disease severity).

Validation of the RPA model as described above on Vitis hybrids (Delaware and Rosette) had a sensitivity of 0.40 and a specificity of 0.33 , and resulted in 5 of 8 years with disease misclassifications (Table 4). In this model, four false negatives occurred. The decision scheme placed both 1985 and 2010 into the 80\% Mild category, when they were both truly Severe ( $\geq 9 \%$ cluster severity). In 1984 and 2011, the RPA model classified the years as $100 \%$ Mild when, in actuality, they were Severe. A false-positive misclassification occurred in 2008, when the model predicted $100 \%$ Severe but it was, in fact, a Mild year. When validating the model using the Chardonnay data for the years 2003 and 2005 to 2010, the use of either the LRA or RPA models resulted in only one instance of misclassification out of the 7 years examined. The LRA model on Chardonnay had a sensitivity of 1.00 and a specificity of 0.66 , and the RPA model had a sensitivity of 0.75 and a specificity of 0.66 . As with the hybrid data, both models predicted a Severe year in 2008 when, in fact, it was Mild for Chardonnay (Table 5).

A week-by-week comparison of the LRA and RPA models for the validation years showed that the weeks immediately surrounding bloom had the largest influence of final cluster severity outcome, and the encompassing weeks acted as modifiers to these predictions (Table 4). In some cases, the weeks after bloom, particularly the last 2 weeks, corresponding to approximately $\mathrm{BBCH}$ phenology growth stage 27 to 31 (Lorenz et al. 1994), shifted the RPA model to a false negative. This was seen in 1984, when the last 2 weeks indicated a Mild year whereas, in fact, it was Severe. It was also seen in 1985, when the last week indicated an $80 \%$ Mild year whereas it was Severe.

Comparing observed and calculated evaporation. For the years of 1986 to 2007 (20 total data years), both calculated $E_{\text {to }}$ and $E_{\text {ow }}$ were significantly lower than observed $\mathrm{E}_{\mathrm{pan}}$. In both cases, regression analysis comparing calculated evaporation values to $\mathrm{E}_{\text {pan }}$ resulted in intercepts not different from $0(-0.43, P=0.66$; and $-1.12 P=0.32$ for $\mathrm{E}_{\mathrm{to}}$ and $\mathrm{E}_{\mathrm{ow}}$, respectively) but slopes were significantly greater than $1\left(P<0.0001\right.$ for both $\mathrm{E}_{\text {to }}$ and $\left.\mathrm{E}_{\mathrm{ow}}\right)$. Slopes were 1.06 and 1.15 for $\mathrm{E}_{\text {to }}$ and $\mathrm{E}_{\mathrm{ow}}$, respectively. The $R^{2}$ values were 0.67 and 0.68 for $\mathrm{E}_{\text {to }}$ and $\mathrm{E}_{\mathrm{ow}}$, respectively.

These regression models were used to adjust calculated values to predict $\mathrm{E}_{\text {pan }}$ values.

Using unadjusted, calculated values of evaporation resulted in more false responses than observed $\mathrm{E}_{\mathrm{pan}}$ values when run through both the LRA- and RPA-derived models. From 1986 to 2007 (excluding 2002 and 2004), using $\mathrm{E}_{\mathrm{pan}}$ in LRA resulted in a model with a sensitivity of 1.00 and a specificity of 0.80 . Using both unadjusted and adjusted (using regression described above) $\mathrm{E}_{\mathrm{to}}$ decreased sensitivity to 0.80 and specificity of 0.70 (two false positives and two false negatives). The use of unadjusted $\mathrm{E}_{\mathrm{ow}}$ decreased sensitivity to 0.80 but maintained specificity. The use of adjusted $\mathrm{E}_{\mathrm{ow}}$ decreased model sensitivity to 0.90 and specificity to 0.70 relative to the use of $E_{\text {pan. }}$. In the case of false-negative predictions when using adjusted $\mathrm{E}_{\mathrm{ow}}$

Table 4. Comparing logistic regression analysis (LRA) and recursive partition analysis (RPA) for model validation on Vitis interspecific hybrids using weekly accumulating evapotranspiration measured from a Class A meteorological pan averages for years 1981, 1983 to 1985, and 2008 to 2011 in New York State

Risk classification

\begin{tabular}{|c|c|c|c|c|c|c|c|c|c|c|}
\hline Year & Analysis $^{b}$ & 1-7 June & 1-15 June & 1-21 June & 1-30 June & 1 June-7 July & 1 June-15 July & 1 June-21 July & 1 June-31 July & $\operatorname{ODS}(\%)^{\mathrm{c}}$ \\
\hline \multirow[t]{2}{*}{1981} & LRA & Severe & Severe & Severe & Severe & Severe & Severe & Severe & Severe & 42.0 (Severe) \\
\hline & RPA & Severe & Severe & Severe & Severe & Severe & Severe & Mild & Severe & $\ldots$ \\
\hline \multirow[t]{2}{*}{1983} & LRA & Severe & Mild & Mild & Mild & Mild & Mild & Mild & Mild & 1.6 (Mild) \\
\hline & RPA & $60 \% \mathrm{~S}$ & $60 \% \mathrm{~S}$ & $80 \% \mathrm{M}$ & $80 \% \mathrm{M}$ & Mild & Mild & Mild & Mild & \\
\hline \multirow[t]{2}{*}{1984} & LRA & Severe & Mild & Severe & Severe & Severe & Severe & Severe & Severe & 32.3 (Severe) \\
\hline & RPA & Severe & Mild & Mild & Mild & Severe & Severe & Mild & Mild & $\ldots$ \\
\hline \multirow[t]{2}{*}{1985} & LRA & Severe & Severe & Severe & Severe & Severe & Severe & Severe & Severe & 14.0 (Severe) \\
\hline & RPA & $60 \% \mathrm{~S}$ & $60 \% \mathrm{~S}$ & $60 \% \mathrm{~S}$ & $60 \% \mathrm{~S}$ & $60 \% \mathrm{~S}$ & $60 \% \mathrm{~S}$ & $60 \% \mathrm{~S}$ & $80 \% \mathrm{M}$ & $\ldots$ \\
\hline \multirow[t]{2}{*}{2008} & LRA & Severe & Severe & Severe & Severe & Severe & Severe & Severe & Severe & 2.8 (Mild) \\
\hline & RPA & Severe & Mild & Severe & Severe & Severe & Severe & Severe & Severe & $\ldots$ \\
\hline \multirow[t]{2}{*}{2009} & LRA & Severe & Severe & Severe & Severe & Severe & Severe & Severe & Severe & 23.0 (Severe) \\
\hline & RPA & $60 \% \mathrm{~S}$ & $60 \% \mathrm{~S}$ & $60 \% \mathrm{~S}$ & $60 \% \mathrm{~S}$ & $60 \% \mathrm{~S}$ & $60 \% \mathrm{~S}$ & $60 \% \mathrm{~S}$ & $60 \% \mathrm{~S}$ & \\
\hline \multirow[t]{2}{*}{2010} & LRA & Mild & Severe & Severe & Severe & Severe & Severe & Severe & Severe & 50.5 (Severe) \\
\hline & RPA & Mild & $60 \% \mathrm{~S}$ & $60 \% \mathrm{~S}$ & $60 \% \mathrm{~S}$ & $80 \% \mathrm{M}$ & $80 \% \mathrm{M}$ & $80 \% \mathrm{M}$ & $80 \% \mathrm{M}$ & $\ldots$ \\
\hline \multirow[t]{2}{*}{2011} & LRA & Mild & Severe & Severe & Severe & Mild & Mild & Mild & Mild & 29.3 (Severe) \\
\hline & RPA & Mild & Mild & Mild & Severe & Mild & Mild & Mild & Mild & $\ldots$ \\
\hline
\end{tabular}

\footnotetext{
a $\mathrm{M}=$ Mild and $\mathrm{S}=$ Severe.

b For the logistic regression model, a year was classified as Severe if the predicted probability from the model was 0.29 or greater based on analysis of the receiver operating characteristic curve.
}

c Observed disease severity. 
(prediction of a Mild year when it was, in fact, classified as a Severe year), those occurred for years with disease severity rating at the lower end of the Severe category (9.35 and $11.39 \%$ for 1998 and 2005, respectively). Overall, although not an ideal substitute, the use of adjusted $E_{o w}$ when using LRA to calculate potential disease risk resulted in fewer false negatives than the use of adjusted $\mathrm{E}_{\mathrm{to}}$.

Excluding 2002 and 2004 in the RPA model resulted in a model sensitivity and specificity of 0.90 when using $\mathrm{E}_{\mathrm{pan}}$. Using unadjusted $\mathrm{E}_{\text {to }}$ reduced sensitivity and specificity to 0.80 , and using unadjusted $\mathrm{E}_{\text {ow }}$ decreased sensitivity to 0.60 but increased specificity to 0.90 (one false positive and four false negatives). Adjusting $\mathrm{E}_{\mathrm{to}}$ as described above reduced sensitivity to 0.80 and specificity to 0.70 relative to using $\mathrm{E}_{\mathrm{pan}}$. Adjusting $\mathrm{E}_{\mathrm{ow}}$ decreased both sensitivity and specificity to 0.70 relative to the use of $\mathrm{E}_{\mathrm{pan}}$. When considering the use of RPA to determine potential risk, unadjusted $\mathrm{E}_{\text {to }}$ outperformed other $\mathrm{E}_{\mathrm{pan}}$ alternatives; however, it did not improve overall model performance. The use of all $\mathrm{E}_{\mathrm{pan}}$ alternatives in the RPA model increased the frequency of false negatives (predicting Mild when the years were, in fact, Severe).

Monte Carlo simulation of calculated $\mathbf{E}_{\mathrm{to}}$ with historical weather inputs. The probability range of the occurrence of conducive weather for high disease severity ((low calculated $\mathrm{E}_{\mathrm{to}}$ ) in New York from 2 weeks prebloom to 6 weeks postbloom, when fruit were at their peak susceptibility, was 0.60 to 0.96 (Table 6). Historically, high calculated $\mathrm{E}_{\text {to }}$ values, predicted to limit powdery mildew development, were most likely to occur immediately following bloom (22 June to 28 June; Table 6). Low calculated $\mathrm{E}_{\text {to }}$ values that would indicate favorable conditions for powdery mildew development were most likely to occur the first week of June, and between 4 and 6 weeks postbloom.

\section{Discussion}

Two critical periods for estimating powdery mildew risk in New York were indicated by our analysis and model. The first period corresponded to a time frame in the epidemic cycle when the overwintering chasmothecia of E. necator are forming and maturing (Gadoury and Pearson 1988). Late summer and early fall temperatures can slow production and maturation of chasmothecia if excessively cool, or accelerate development if temperatures are optimal (Gadoury and Pearson 1988). This was highlighted in the present study by the inclusion of DD during this period as a determinant of followingyear disease severity.

The temporal aspects of ascocarp formation and subsequent spore release are of particular interest in the epidemic development of grape powdery mildew. The variable weather during formation of E. necator chasmothecia results in the production of cohorts of ascocarps that influence the timing and distribution of ascospore release the following spring (Moyer et al. 2014; Rossi et al. 2010). Occurrence of killing frosts and premature defoliation can preclude the survival of late-developing ascocarps, particularly if chasmothecia have not yet achieved physiological maturity and detached from the grapevine leaf (Gadoury and Pearson 1988). Thus, the previous season's weather (in particular, temperature) may determine both the absolute quantity of ascosporic inoculum and the timing of its release with respect to host development the following spring.

Ascospore release during periods in which the host is dormant has been repeatedly observed (Gee et al. 2000; Moyer et al. 2014; Rossi et al. 2010). Likewise, cohorts that release ascospores in the earliest phases of host growth may have their subsequent growth suppressed by acute low overnight temperatures that occur not only in New York but also in nearly all viticultural regions before bloom (Moyer et al. 2010). Primary inoculum dose becomes increasingly influential when the reproductive rate of the pathogen is slowed by an unfavorable environment and when the susceptible period for a host organ is limited to the early stages of an epidemic (Caffi et al. 2011; Moyer et al. 2014; Rossi et al. 2010; Vanderplank 1963). Primary inoculum becomes less important as the favorability of disease development (i.e., the epidemic rate) and epidemic duration increase. However, high levels of primary inoculum and favorable conditions will lead to maximum disease severity. This will shift the temporal window of rapid disease development from midsummer, corresponding to

Table 6. Output of Monte Carlo simulation for evapotranspiration $\left(\mathrm{E}_{\mathrm{to}}\right)$ in New York State using historical weather data

\begin{tabular}{lcccc}
\hline Week & $\begin{array}{c}\text { Mean } \\
\mathbf{E}_{\text {to }} \\
(\mathbf{m m})\end{array}$ & $\begin{array}{c}\mathbf{9 0 \%} \\
\mathbf{c e n t r a l} \\
\text { range }(\mathbf{m m})\end{array}$ & $\begin{array}{c}\text { Probability } \\
\left(\mathbf{E}_{\mathbf{t o}}<\mathbf{5 . 4 5}\right. \\
\mathbf{m m})^{\mathbf{a}}\end{array}$ & $\begin{array}{c}\text { Probability } \\
\left(\mathbf{E}_{\mathbf{t o}}>\mathbf{6 . 0 7}\right. \\
\mathbf{m m})^{\mathbf{a}}\end{array}$ \\
\hline 1-7 June & 4.45 & $3.46-5.46$ & 0.96 & 0.00 \\
8-14 June & 4.91 & $3.61-6.23$ & 0.72 & 0.09 \\
15-21 June & 5.02 & $3.89-6.22$ & 0.70 & 0.09 \\
22-28 June & 5.20 & $3.76-6.69$ & 0.60 & 0.20 \\
29 June to 5 July & 5.07 & $4.09-6.13$ & 0.68 & 0.07 \\
6-12 July & 5.21 & $4.27-6.12$ & 0.67 & 0.07 \\
13-19 July & 5.00 & $3.79-6.20$ & 0.69 & 0.10 \\
20-26 July & 4.86 & $3.85-5.89$ & 0.80 & 0.02 \\
27 July to & 4.80 & $3.52-6.13$ & 0.74 & 0.07 \\
2 August & & & & \\
\hline
\end{tabular}

${ }^{a}$ Indicated cardinal $\mathrm{E}_{\text {to }}$ values, used as a proxy for evapotranspiration measured from a Class A meteorological pan, for a "dry" (>6.07 mm, Mild) or a "wet" $(<5.45 \mathrm{~mm}$, Severe) year.

Table 5. Comparing logistic regression analysis (LRA) and recursive partition analysis (RPA) for model validation on Vitis vinifera 'Chardonnay' using weekly accumulating evapotranspiration measured from a Class A meteorological pan averages for years 2003 and 2005 to 2010 in New York State

\begin{tabular}{|c|c|c|c|c|c|c|c|c|c|c|}
\hline \multirow[b]{2}{*}{ Year } & \multirow[b]{2}{*}{ Analysis $^{b}$} & \multicolumn{8}{|c|}{ Risk classification $^{\mathbf{a}}$} & \multirow[b]{2}{*}{$\operatorname{ODS}(\%)^{\mathrm{c}}$} \\
\hline & & 1-7 June & 1-15 June & 1-21 June & 1-30 June & 1 June-7 July & 1 June-15 July & 1 June-21 July & 1 June-31 July & \\
\hline \multirow{2}{*}{2003} & LRA & Severe & Severe & Severe & Severe & Severe & Severe & Severe & Severe & $98.4(\mathrm{~S})$ \\
\hline & RPA & Severe & Severe & Severe & Severe & Severe & Severe & Severe & Severe & $\ldots$ \\
\hline \multirow[t]{2}{*}{2005} & LRA & Severe & Mild & Severe & Mild & Mild & Mild & Mild & Mild & $3.42(\mathrm{M})$ \\
\hline & RPA & $80 \% \mathrm{M}$ & Mild & $80 \% \mathrm{M}$ & Mild & Mild & Mild & Mild & $80 \% \mathrm{M}$ & \\
\hline \multirow[t]{2}{*}{2006} & LRA & Severe & Severe & Severe & Severe & Severe & Severe & Severe & Severe & $67.4(\mathrm{~S})$ \\
\hline & RPA & Severe & Severe & Severe & Severe & Severe & Severe & Severe & Severe & \\
\hline \multirow[t]{2}{*}{2007} & LRA & Severe & Mild & Mild & Mild & Mild & Mild & Mild & Mild & $17.9(\mathrm{M})$ \\
\hline & RPA & $60 \% \mathrm{~S}$ & Mild & Mild & Mild & Mild & Mild & Mild & Mild & $\ldots$ \\
\hline \multirow[t]{2}{*}{2008} & LRA & Severe & Severe & Severe & Severe & Severe & Severe & Severe & Severe & $25.8(\mathrm{M})$ \\
\hline & RPA & Severe & Mild & Severe & Severe & Severe & Severe & Severe & Severe & $\ldots$ \\
\hline \multirow[t]{2}{*}{2009} & LRA & Severe & Severe & Severe & Severe & Severe & Severe & Severe & Severe & $99.0(\mathrm{~S})$ \\
\hline & RPA & $60 \% \mathrm{~S}$ & $60 \% \mathrm{~S}$ & $60 \% \mathrm{~S}$ & $60 \% \mathrm{~S}$ & $60 \% \mathrm{~S}$ & $60 \% \mathrm{~S}$ & $60 \% \mathrm{~S}$ & $60 \% \mathrm{~S}$ & ... \\
\hline \multirow[t]{2}{*}{2010} & LRA & Mild & Severe & Severe & Severe & Severe & Severe & Severe & Severe & $99.5(\mathrm{~S})$ \\
\hline & RPA & Mild & $60 \% \mathrm{~S}$ & $60 \% \mathrm{~S}$ & $60 \% \mathrm{~S}$ & $80 \% \mathrm{M}$ & $80 \% \mathrm{M}$ & $80 \% \mathrm{M}$ & $80 \% \mathrm{M}$ & $\ldots$ \\
\hline
\end{tabular}

\footnotetext{
${ }^{a} \mathrm{M}=$ Mild and $\mathrm{S}=$ Severe.

${ }^{\mathrm{b}}$ For the logistic regression model, a year was classified as Severe if the predicted probability from the model was 0.29 or greater to minimize false-negative predictions based on analysis of the receiver operating characteristic curve.
}

c Observed disease severity. 
an epidemic on the vine foliage, to an earlier period more directly aligned with peak berry susceptibility to infection.

The second period identified for estimation of disease severity risk corresponded to time frame from prebloom $(\mathrm{BBCH} 17)$ to fruit set (BBCH 27), when elongating inflorescences and subsequent developing berries are highly susceptible to E. necator infection (Ficke et al. 2002, 2003, 2004; Gadoury et al. 2001, 2003b). This period is also coincident with the time of exponential increase of secondary inoculum (Seem 1984), and when overnight temperatures typically have increased to the point where they no longer induce transient resistance in ordinarily susceptible tissues and, thereby, suppress colony survival, colony expansion, and sporulation (Moyer et al. 2010). A model of Fusarium head blight of wheat uses similar host phenological inputs related to pathogen survival and inoculum dissemination to refine predictions of disease risk (De Wolf et al. 2003). During this second time frame, evapotranspiration, which is a function of the three major environmental factors that influence development of E. necator (T [Delp 1954], VPD [Carroll and Wilcox 2003], and SR [Austin and Wilcox 2012]) plus the modifying effects of wind, was the single best integrative, measurable unit for risk modeling. $\mathrm{E}_{\mathrm{pan}}$ was negatively correlated with the outcome of final disease severity on grape clusters. High $\mathrm{E}_{\mathrm{pan}}$ days are characterized by dry air, intense SR, warmer temperatures, and higher wind speeds. This finding is consistent with other reports that have shown that viticultural practices such as leaf removal, which increase VPD and sunlight within the removal zone and, thus, increase evaporation potential, can reduce disease severity (Austin and Wilcox 2011; 2012; Austin et al. 2011; English et al. 1990).

Weekly changes in model output over the course of the season provided interesting insight into epidemic development. $\mathrm{E}_{\text {pan }}$ leading up to and during bloom was a good determinant of disease severity at harvest, and subsequent weather conditions moderated the level of predicted severity. For example, 1984 (32.3\% cluster severity) was classified as a Mild year for powdery mildew by the RPA model over the entire modeled period. However, the model predicted a severe outbreak when calculated with weather data through 4 weeks post bloom rather than at 4 weeks post fruit set. This highlights the importance of considering model performance during phenologically relevant stages of vine development. The time frames that were selected for the entire model were those that encompassed key phenological stages over a 30-year period and thus, on a yearly basis, may include time periods beyond those that are relevant to the development of ontogenic resistance in that particular season (Ficke et al. 2003).

Validation of the two models using data from both Vitis hybrids and Chardonnay showed that the LRA model had fewer instances of false negatives ( 1 overall for a total of 15 observations) as well as false positives ( 2 overall for 15 observations). This reduction in false outcomes indicates that this particular model format would be best used for predicting Mild or Severe years. False positives in this system can result in the unnecessary application of fungicides. However, although unnecessary sprays may result in economic loss due to the cost associated with the application, the lack of providing sufficient spray applications when they are necessary (as would happen in response to a false negative) could result in crop damage. Thus, although there are negative economic consequences associated with false positives in this scenario, they may be considered less consequential than those that would result from a lack of intervention associated with a false-negative output. The LRA model requires a calculation for estimating disease risk. Although this could be easily done in an automated model, the use of decision trees, as developed through RPA, allows a quick, rapid assessment of disease risk.

The decision-tree scheme for the RPA model resulted in four false negatives and two false positives for the 15 observations used in the validation process. The false negatives occurred in 1984, 1985, 2010, and 2011 in the Vitis hybrid datasets. Both 1984 and 2011were classified as $100 \%$ Mild; 1985 and 2010 were classified as $80 \%$ Mild. In all four cases, observed data indicated that they were Severe years. The 1984 year was dry around bloom but the first week of June and the first half of July had ratings that classified it as Severe. A likely scenario is that the abundance of overwintering primary inoculum (late summer 1983 had over 500 DD $_{10}$ units) was able to establish quickly in the first week of June. Development of powdery mildew from June to mid-July is crucial in determining inoculum potential for infection of clusters during their relatively brief susceptible period (Ficke et al. 2003; Moyer et al. 2014). A similar situation was seen in 2011, where most of the season was classified as Mild but $\mathrm{E}_{\mathrm{pan}}$ was low near bloom and, coupled with a previous warm fall, likely resulted in maximized development of the disease. In 1985, the predicted weekly ratings were $60 \%$ Severe at the beginning of the growing season but a substantial increase in $\mathrm{E}_{\mathrm{pan}}$ during the last week of July shifted predicted disease risk into the $80 \%$ Mild prediction category. A similar pattern was seen in 2010.

In the Chardonnay data set, a false positive occurred in 2008, when it was predicted to be $100 \%$ Severe when it was, in fact, Mild. That year had several instances of cold overnight lows $\left(<8^{\circ} \mathrm{C}\right)$ in late May (28, 29, and 30 May), approximately 3 weeks before bloom, that may have substantially limited early-season epidemic development (Moyer et al. 2010).

One drawback to using $\mathrm{E}_{\mathrm{pan}}$ as a model input is the level of effort needed to maintain a Class A meteorological pan. Although global $\mathrm{E}_{\mathrm{pan}}$ networks exist, the quality and consistency of data are a concern. To overcome this, many networks use calculated $\mathrm{E}_{\mathrm{to}}$. For Geneva, $\mathrm{NY}$, our comparisons showed that the use of calculated $\mathrm{E}_{\mathrm{to}}$ and calculated $\mathrm{E}_{\mathrm{ow}}$ reduces model performance but may provide an alternative for locations that do not have $\mathrm{E}_{\mathrm{pan}}$ data readily available. In many cases, extremes in $\mathrm{E}_{\text {pan }}$ values are lost when calculating $\mathrm{E}_{\mathrm{to}}$, and these extreme values are those that may strongly influence powdery mildew epidemics. One of the benefits to using calculated evaporation values rather than measured values is that they can then be used to forecast evaporation if their input values have the ability to be forecasted. Forecast temperature can be easily substituted for observed data in calculating $\mathrm{E}_{\mathrm{to}}$ or $\mathrm{E}_{\mathrm{ow}}$, because temperature can be reliably predicted out to several days in advance, as seen in the presented Monte Carlo simulation of predicted $\mathrm{E}_{\mathrm{to}}$. This would allow a predicted estimate of disease risk and allow appropriate preventative management strategies to be put in place in anticipation of changing disease pressure. However, further site-specific development of $\mathrm{E}_{\text {to }}$ thresholds may be needed, particularly if an RPA-like model were to be used with specific threshold values. The use of $E_{\text {to }}$ in the LRA model was less influential, as noted by the low but existent falsenegative rate.

Considering other models and their potential outcomes when used in New York highlights how forecasts of grapevine powdery mildew can be affected by key limiting environmental conditions present in a model's region of origin. The Powdery Mildew Index, originating in California (Gubler et al. 2009), was designed to provide guidance on the interval between fungicide applications based on favorability of daily temperatures for powdery mildew. High temperatures (i.e., $>34^{\circ} \mathrm{C}$ ) that persist for specific durations function as a limiting factor to disease development, and the calculated risk values are intended to reflect this affect (Peduto et al. 2013). Thus, this index is particularly suited to improving the timing of fungicide applications and avoiding unnecessary sprays in climates where limiting high temperatures regularly occur. However, such conditions rarely develop in New York. Daily maximum temperatures at Geneva, NY exceeded $34^{\circ} \mathrm{C}$ for an average of 1.2 days a year from 2005 through 2009, inclusive, versus 36.8 days per year at Davis, CA over the same period.

OiDiag 2.2 (Kast and Bleyer 2010) incorporates a prediction of inoculum potential based on winter survival of dormant infected buds, and the subsequent generation of heavily sporulating flag shoots. This system was developed in Weinsburg, Germany, a climate with markedly warmer winters than Geneva, NY (e.g., an average temperature of $1.5^{\circ} \mathrm{C}$ compared with $-4.1^{\circ} \mathrm{C}$ for Geneva, NY from 1 December to 1 March). Pearson and Gadoury (1987) extensively surveyed New York vineyards (54,000 vines over a period of 3 years) and were unable to find any evidence of survival of E. necator as mycelium in dormant infected buds. Presumably, winter temperatures are invariably low enough in New York to preclude survival of the less-hardy infected buds (Pearson and Gartel 1985; Pearson and 
Gadoury 1987). Thus, models that use flag shoots as the main source of primary inoculum may underestimate initial disease in areas with colder winters. From the standpoint of practical use of these models, the aforementioned examples highlight the need to understand the reasoning behind model inputs and how those inputs may (or may not) be appropriately adapted for local conditions or disease epidemiology. Regional consideration of typical disease progress is needed for the proper interpretation of model outputs for both the currently presented models and previously published models.

In conclusion, the present study describes the foundation of a risk forecasting system for powdery mildew infection of both hybrid and $V$. vinifera fruit in New York State. This model focuses on two key time frames in the epidemiology of powdery mildew: the time when primary inoculum is forming and the time when grape berries are at their peak susceptibility to E. necator. The limited period of berry susceptibility is circumscribed by a finite period of host development; the duration of this critical period of fruit development can be predicted by other models (Parker et al. 2011) and, when combined with predicted evapotranspiration and real-time weather forecasts, provides the unique ability to model severity risk of berry infection.

\section{Acknowledgments}

This work was supported by the United States Department of Agriculture Viticulture Consortium-East, The Pennsylvania Wine Marketing Board, the New York Wine and Grape Foundation, the American Society for Enology and Viticulture National and Eastern Sections, and the American Wine Society. The research described herein represents a portion of a dissertation submitted by M. M. Moyer to the Graduate School of Cornell University in partial fulfillment of requirements for the Ph.D. in Plant Pathology. We thank G. Hill for guidance and updates regarding the use of the OiDiag 2.2 expert system and P. A. Magarey for discussion and guidance on powdery mildew modeling.

\section{Literature Cited}

Allen, R. G., Pereira, L. S., Raes, D., and Smith, M. 1998. Crop Evapotranspiration-Guidelines for Computing Crop Water Requirements. FAO Irrigation and Drainage Papers 56. Food and Agriculture Organization of the United Nations, Rome.

Austin, C. N., Grove, G. G., Meyers, J. M., and Wilcox, W. F. 2011. Powdery mildew severity as a function of canopy density: Associated Impacts on sunlight penetration and spray coverage. Am. J. Enol. Vitic. 62:23-31.

Austin, C. N., and Wilcox, W. F. 2011. Effects of fruit-zone leaf removal, training systems, and irrigation on the development of grapevine powdery mildew. Am. J. Enol. Vitic. 62:193-198.

Austin, C. N., and Wilcox, W. F. 2012. Effects of sunlight exposure on grapevine powdery mildew development. Phytopathology 102:857-866.

Caffi, T., Legler, S. E., and Rossi, V. 2012. Evaluation of a warning system for early-season control of grapevine powdery mildew. Plant Dis. 96:104-110.

Caffi, T., Rossi, V., Legler, S. E., and Bugiani, R. 2011. A mechanistic model simulating ascosporic infections by Erysiphe necator, the powdery mildew fungus of grapevine. Plant Pathol. 60:522-531.

Calonnec, A., Cartolaro, P., Naulin, J. M., Bailey, D., and Langlais, M. 2008. A hostpathogen simulation model: Powdery mildew of grapevine. Plant Pathol. 57:493-508.

Carisse, O., Bacon, R., and Lefebvre, A. 2009. Grape powdery mildew (Erysiphe necator) risk assessment based on airborne conidium concentration. Crop Prot. 28:1036-1044.

Carroll, J. E., and Wilcox, W. F. 2003. Effects of humidity on the development of grapevine powdery mildew. Phytopathology 93:1137-1144.

Chellemi, D. O., and Marois, J. J. 1991a. Development of a demographic growth model for Uncinula necator by using a microcomputer spreadsheet program. Phytopathology 81:250-254.

Chellemi, D. O., and Marois, J. J. 1991b. Sporulation of Uncinula necator on grape leaves as influenced by temperature and cultivar. Phytopathology 81:197-201.

Cook, E. F., and Goldman, L. 1984. Empiric comparison of multivariate analytical techniques: Advantages and disadvantages of recursive partitioning analysis. J. Chronic Dis. 37:721-731.

Delp, C. J. 1954. Effect of temperature and humidity on the grape powdery mildew fungus. Phytopathology 44:615-626.

De Wolf, E. D., Madden, L. V., and Lipps, P. E. 2003. Risk assessment models for wheat Fusarium Head Blight epidemics based on within-season weather data. Phytopathology 93:428-435.

English, J. T., Bledsoe, A. M., and Marois, J. J. 1990. Influence of leaf removal from the fruit cluster zone on the components of evaporative potential within grapevine canopies. Agric. Ecosyst. Environ. 31:49-61.

Feddes, R. A., and Lenselink, K. J. 1994. Evapotranspiration. Pages 145-224 in: Drainage Principles and Applications. ILRI Publ. 16, 2nd. H. P. Ritzema, ed. ILRI Wageningen, Wageningen, The Netherlands.

Ficke, A., Gadoury, D. M., and Seem, R. C. 2002. Ontogenic resistance and plant disease management: A case study of grape powdery mildew. Phytopathology 92:671-675.
Ficke, A., Gadoury, D. M., Seem, R. C., and Dry, I. B. 2003. Effects of ontogenic resistance upon establishment and growth of Uncinula necator on grape berries. Phytopathology 93:556-563.

Ficke, A., Gadoury, D. M., Seem, R. C., Godfrey, D., and Dry, I. B. 2004. Host barriers and responses to Uncinula necator in developing grape berries. Phytopathology 94:438-445.

Gadoury, D. M., and Pearson, R. C. 1988. Initiation, development, dispersal and survival of cleistothecia of Uncinula necator in New York vineyards. Phytopathology 78:1413-1421.

Gadoury, D. M., Pearson, R. C., Seem, R. C., and Park, E. W. 1997a. Integrating the control programs for fungal diseases of grapevine in the northeastern United States. Vitic. Enol. Sci. 52:140-147.

Gadoury, D. M., Seem, R. C., Ficke, A., and Wilcox, W. F. 2001. The epidemiology of powdery mildew on Concord grapes. Phytopathology 91: 948-955.

Gadoury, D. M., Seem, R. C., Ficke, A., and Wilcox, W. F. 2003a. Climate-based temporal heterogeneity in flowering and the distribution of ontogenic resistance to major fruit diseases of grapevine. (Abstr.) Phytopathology 93:S28.

Gadoury, D. M., Seem, R. C., Ficke, A., and Wilcox, W. F. 2003b. Ontogenic resistance to powdery mildew in grape berries. Phytopathology 93:547-555.

Gadoury, D. M., Seem, R. C., Magarey, P. A., Emmett, R., and Magarey, R. 1997b. Effects of environment and fungicides on epidemics of grape powdery mildew: Considerations for practical model development and disease management. Vitic. Enol. Sci. 52:225-229.

Gadoury, D. M., Seem, R. C., Wilcox, W. F., Henick-Kling, T., Conterno, L., Day, A., and Ficke, A. 2007. Effects of diffuse colonization of grape berries by Uncinula necator on bunch rots, berry microflora, and juice and wine quality. Phytopathology 97:1356-1365.

Gee, C. T., Gadoury, D. M., and Cadle-Davidson, L. 2008. Ontogenic resistance to Uncinula necator varies by genotype and tissue type in a diverse collection of Vitis spp. Plant Dis. 92:1067-1073.

Gee, L. M., Stummer, B. E., Gadoury, D. M., Biggins, L. T., and Scott, E. S. 2000. Maturation of cleistothecia of Uncinula necator (powdery mildew) and release of ascospores in southern Australia. Aust. J. Grape Wine Res. 6:13-20.

Gubler, W. D., Smith, R. J., Varela, L. G., Vasquez, S. J., Stapleton, J. J., Purcell, A. H., and Leavitt, G. M. 2009. UC IPM Pest Management Guidelines: Grape. UC ANR Publ. 3448. University of California, Richmond, CA.

Hilbe, J. M. 2009:Page 637 in: Logistic Regression Models. CRC Press, Boca Raton, FL.

Hill, G. K. 1990. The influence of annual weather patterns on epidemics of Uncinula necator in Rheinhessen. Vitic. Enol. Sci. 45:43-46.

Kast, W. K. 1997. A step by step risk analysis (SRA) used for planning sprays against powdery mildew (OiDiag-System). Vitic. Enol. Sci. 52:230-231.

Kast, W. K., and Bleyer, K. 2010. The expert system OiDiag-2.2- a useful tool for the precise scheduling of sprays against powdery mildew of vine (Erysiphe necator) Schwein. In: Proc. 6th Int. Workshop Grapevine Downy and Powdery Mildew, Bordeaux 2010. A. Calonnec, F. Delmotte, R. Emmett, D. M Gadoury, C. Gessler, W. D. Gubler, H. Kassemeyer, P. A. Magarey, M. Raynal, and R. C. Seem, eds. INRA-INITA, Bordeaux, France.

Large, E. C. 1940. The Advance of the Fungi. Henry Holt and Co., New York.

Lorenz, D. H., Eichhorn, K. W., Bleiholder, H., Klose, R., Meier, U., and Weber, E. 1994. Phaenologische Entwicklungsstadien der Weinrebe (Vitis vinifera L. ssp. vinifera). Codierung und Beschreibung nach der erweiterten BBCHSkala. Vitic. Enol. Sci. 49:66-70.

Moyer, M. M., Gadoury, D. M., Cadle-Davidson, L., Dry, I. B., Magarey, P. A., Wilcox, W. F., and Seem, R. C. 2010. Effects of acute low temperature events on the development of Erysiphe necator and susceptibility of Vitis vinifera. Phytopathology 100:1240-1249.

Moyer, M. M., Gadoury, D. M., Seem, R. C., and Wilcox, W. F. 2007. Towards an advisory system for grapevine powdery mildew in cooler climates. (Abstr.) Phytopathology 97:S80.

Moyer, M. M., Gadoury, D. M., Wilcox, W. F., and Seem, R. C. 2014. Release of Erysiphe necator ascospores and impact of early-season disease pressure on Vitis vinifera fruit infection. Am. J. Enol. Vitic. 65:315-324.

Nail, W. R., and Howell, G. S. 2005. Effects of timing of powdery mildew infection on carbon assimilation and subsequent seasonal growth of potted Chardonnay grapevines. Am. J. Enol. Vitic. 56:220-227.

Parker, A. K., De Cortázar-Atauri, I. G., Van Leeuwen, C., and Chuine, I. 2011 General phenological model to characterise the timing of flowering and veraison of Vitis vinifera L. Aust. J. Grape Wine Res. 17:206-216.

Pearson, R. C., and Gadoury, D. M. 1987. Cleistothecia, the source of primary inoculum for grape powdery mildew in New York. Phytopathology 77:1509-1514.

Pearson, R. C., and Gadoury, D. M. 1992. Powdery mildew of grape. Pages 129-146 in: Plant Diseases of International Importance, Vol. 3. J. Kumar, H. S. Chaube, U. S. Singh, and A. N. Mukhopadhyay, eds. Prentice Hall, Englewood Cliffs, NJ.

Pearson, R. C., and Gartel, W. 1985. Occurrence of hyphae of Uncinula necator in buds of grapevine. Plant Dis. 69:149-151.

Pearson, R. C., and Riegel, D. G. 1984. Efficacy of fungicides for control of powdery mildew on grapes, 1983. Fungic. Nematicide Tests 39:53.

Pearson, R. C., and Riegel, D. G. 1985. Evaluation of experimental fungicides on a reduced schedule for control of powdery mildew on grapes, 1984. Fungic Nematicide Tests 40:60. 
Pearson, R. C., and Riegel, D. G. 1986. Evaluation of experimental fungicides for control of powdery mildew on grapes, 1985 . Fungic. Nematicide Tests 41:42-43.

Pearson, R. C., and Riegel, D. G. 1987. Evaluation of experimental fungicides for control of powdery mildew on grapes, 1986. Fungic. Nematicide Tests 42:51.

Pearson, R. C., and Riegel, D. G. 1988. Evaluation of experimental fungicides applied at extended intervals for control of powdery mildew and black rot of grapes, 1987. Fungic. Nematicide Tests 43:91.

Pearson, R. C., and Riegel, D. G. 1990. Evaluation of experimental fungicides for control of powdery mildew of grapes, 1989. Fungic. Nematicide Tests 45:73.

Pearson, R. C., and Riegel, D. G. 1991. Evaluation of fungicides for control of powdery mildew on grapes, 1990. Fungic. Nematicide Tests 46:89.

Pearson, R. C., and Riegel, D. G. 1992. Evaluation of fungicides for control of powdery mildew of grapes, 1991. Fungic. Nematicide Tests 47:65.

Pearson, R. C., and Riegel, D. G. 1993. Evaluation of fungicides for control of powdery mildew of grapes, 1992. Fungic. Nematicide Tests 48:79.

Pearson, R. C., and Riegel, D. G. 1994. Evaluation of fungicides for control of powdery mildew of grapes, 1993. Fungic. Nematicide Tests 49:70.

Pearson, R. C., and Riegel, D. G. 1995. Evaluation of fungicides for control of powdery mildew of grapes, 1994. Fungic. Nematicide Tests 50:74.

Peduto, F., Backup, P., Hand, E. K., Janousek, C. N., and Gubler, W. D. 2013. Effect of high temperature and exposure time on Erysiphe necator growth and reproduction: Revisions to the UC Davis powdery mildew risk index. Plant Dis. 97:1438-1447.

Pool, R. M., Pearson, R. C., Welser, M. J., Lakso, A. N., and Seem, R. C. 1984. Influence of powdery mildew on yield and growth of Rosette grapevines. Plant Dis. 68:590-593.

Rossi, V., Caffi, T., and Legler, S. E. 2010. Dynamics of ascospore maturation and discharge in Erysiphe necator, the causal agent of grape powdery mildew. Phytopathology 100:1321-1329.

Sall, M. A. 1980. Epidemiology of grape powdery mildew: A model. Phytopathology 70:338-342.

Savary, S., Delbac, L., Rochas, A., Taisant, G., and Willocquet, L. 2009. Analysis of nonlinear relationships in dual epidemics, and its application to the management of grapevine downy and powdery mildews. Phytopathology 99: 930-942.

Seem, R. C. 1984. Disease incidence and severity relationships. Annu. Rev. Phytopathol. 22:133-150.

Smart, R., and Robinson, M. 1991. Sunlight Into Wine: A Handbook for Winegrape Canopy Management. Winetitles, Adelaide, SA.

Vanderplank, J. E. 1963. Plant Diseases: Epidemics and Control. Academic Press, New York.

Wilcox, W. F., English-Loeb, G., Dunst, R. M., and Landers, A. 2010:Page 93 in: New York and Pennsylvania Pest Management Guidelines for Grapes. Cornell University, Ithaca, NY.

Wilcox, W. F., and Riegel, D. G. 1996. Evaluation of fungicides and spray timings for control of grape powdery mildew, 1995. Fungic. Nematicide Tests 51:76.

Wilcox, W. F., and Riegel, D. G. 1997. Evaluation of fungicides programs for control of grapevine powdery mildew, 1996. Fungic. Nematicide Tests 52:82.

Wilcox, W. F., and Riegel, D. G. 1998. Evaluation of fungicide programs for control of grapevine powdery mildew, 1997. Fungic. Nematicide Tests 53:107.

Wilcox, W. F., and Riegel, D. G. 1999. Evaluation of fungicide programs for control of grapevine powdery mildew, 1998. Fungic. Nematicide Tests 54:106-107.

Wilcox, W. F., and Riegel, D. G. 2000. Evaluation of fungicide programs for control of grapevine powdery mildew, 1999. Fungic. Nematicide Tests 55:119.

Wilcox, W. F., and Riegel, D. G. 2001. Evaluation of fungicide programs for control of grapevine powdery mildew, 2000. Online publication. Fungic. Nematicide Tests 56:SMF36. doi:10.1094/FN56
Wilcox, W. F., and Riegel, D. G. 2002. Evaluation of fungicide programs for control of grapevine powdery mildew, 2001. Online publication. Fungic. Nematicide Tests 57:SMF20. doi:10.1094/FN57

Wilcox, W. F., and Riegel, D. G. 2003. Evaluation of fungicide programs for control of grapevine powdery mildew, 2002. Online publication. Fungic. Nematicide Tests 58:SMF045. doi:10.1094/FN58

Wilcox, W. F., and Riegel, D. G. 2004a. Evaluation of fungicide programs for control of grapevine powdery mildew, 2003. Online publication. Fungic Nematicide Tests 59:SMF010. doi:10.1094/FN59

Wilcox, W. F., and Riegel, D. G. 2004b. Evaluation of fungicide programs for control of grapevine powdery mildew in a strobilurin-resistant site, 2003 Online publication. Fungic. Nematicide Tests 59:SMF011. doi:10.1094/FN59

Wilcox, W. F., and Riegel, D. G. 2005. Evaluation of fungicide programs for control of grapevine powdery mildew, 2004. Online publication. Fungic. Nematicide Tests 60:SMF034. doi:10.1094/FN60

Wilcox, W. F., and Riegel, D. G. 2006a. Evaluation of fungicide programs for control of grapevine powdery mildew, 2005. Online publication. Fungic. Nematicide Tests 61:SMF035. doi:10.1094/FN61

Wilcox, W. F., and Riegel, D. G. 2006b. Evaluation of fungicide programs for control of powdery mildew on Chardonnay grapes, 2005. Online publication. Fungic. Nematicide Tests 61:SMF036. doi:10.1094/FN61

Wilcox, W. F., and Riegel, D. G. 2007a. Evaluation of fungicide programs for control of grapevine powdery mildew in a strobilurin-resistant population, 2006 Online publication. Plant Dis. Manage. Rep. 1:SMF003. doi:10.1094/PDMR01

Wilcox, W. F., and Riegel, D. G. 2007b. Evaluation of fungicide programs for control of grapevine powdery mildew, 2006. Online publication. Plant Dis. Manage. Rep. 01:SMF005. doi:10.1094/PDMR01

Wilcox, W. F., and Riegel, D. G. 2008a. Evaluation of fungicide programs for control of grapevine powdery mildew in a commercial Chardonnay vineyard, 2007. Online publication. Plant Dis. Manage. Rep. 2:STF010. doi:10.1094/PDMR02

Wilcox, W. F., and Riegel, D. G. 2008b. Evaluation of fungicide programs for control of grapevine powdery mildew, 2007. Online publication. Plant Dis. Manage. Rep. 2:STF011. doi:10.1094/PDMR02

Wilcox, W. F., and Riegel, D. G. 2010a. Evaluation of fungicide programs for control of powdery mildew on Chardonnay grapes, 2008. Online publication. Plant Dis. Manage. Rep. 4:SMF046. doi:10.1094/PDMR04

Wilcox, W. F., and Riegel, D. G. 2010b. Evaluation of fungicide programs for control of grapevine powdery mildew, 2009. Online publication. Plant Dis. Manage. Rep. 4:SMF054. doi:10.1094/PDMR04

Wilcox, W. F., and Riegel, D. G. 2010c. Evaluation of fungicide programs for control of powdery mildew on Rosette grapes, 2009. Online publication. Plant Dis. Manage. Rep. 4:SMF055. doi:10.1094/PDMR04

Wilcox, W. F., and Riegel, D. G. 2010d. Evaluation of fungicide programs for control of grapevine powdery mildew, 2008. Online publication. Plant Dis. Manage. Rep. 3:SMF045. doi:10.1094/PDMR04

Wilcox, W. F., and Riegel, D. G. 2012a. Evaluation of fungicide programs for control of grapevine powdery mildew, 2010. Online publication. Plant Dis. Manage. Rep. 6:SMF048. doi:10.1094/PDMR06

Wilcox, W. F., and Riegel, D. G. 2012b. Evaluation of fungicide programs for control of grapevine powdery mildew, 2011. Online publication. Plant Dis. Manage. Rep. 6:SMF044. doi:10.1094/PDMR06

Wilcox, W. F., and Riegel, D. G. 2012c. Evaluation of fungicide programs for control of grapevine powdery mildew, 2010. Online publication. Plant Dis Manage. Rep. 6:SMF049. doi:10.1094/PDMR06

Zahavi, T., Reuveni, M., Scheglov, D., and Lavee, S. 2001. Effect of grapevine training systems on development of powdery mildew. Eur. J. Plant Pathol 107:495-501. 